\title{
A PSYCHOLINGUISTIC ANALYSIS OF WORLD LEADERS' DISCOURSES CONCERNING THE COVID-19 CONTEXT: AUTHENTICITY AND EMOTIONAL TONE
}

\author{
SANDRA FIGUEIREDO, MIGUEL DEVEZAS, NEUZA VIEIRA, ANDRÉ SOARES
}

\begin{abstract}
:
This study aims to examine authentic discourses of eight country leaders, in two different periods of the COVID-19 context, in order to analyze how their authenticity traits and emotional tone might have changed between February and April of 2020 and according to the updated pandemic numbers of each country. Countries and their leaders were selected based on the West and East representation of the North Hemisphere and with no ethnicity concepts attached. It was developed a specific dictionary for this psycholinguistic analysis based in the Linguistic Inquiry and Word Count (LIWC 2015, v. 1.6.0. 2019) and the original version created for this trial study was administered to establish the segmentation and codification of 16 international discourses, focusing leadership and COVID-19 as new contexts. The texts were coded considering the linguistic dimensions and psychological categories. After the dataset of 39073 words concluded, correlation was computed to link linguistic samples with low/high emotional properties (and taking into account the linguistic style of the country' leaders). The word count will not be addressed attending to lexicon frequency, grammar organization and syntax properties of the eight languages. The samples revealed psycholinguistic controversy registered in the two sessions of the leaders' discourses. Results for authenticity have shown that the cases of US, UK and France were more authentic, contrary to Russian and Chinese leaders' discourses. The emotional tone was low and negative $(<.50)$ for the discourses of Spain and Russian Presidents, by comparing to their peers. The discourse analysis by using automated methodologies such as LIWC enhances the correct comprehension and detects the locus of misinformation about the COVID-19 measures and phases. That misinformation, when observed, refers to likely mixed messaging used by individuals to prevent the collapse of their government respecting the impact of their discourses on the public opinion. We will discuss the data obtained concerning the results for different emotional response of the eight leaders and controlling for variables such as the culture and socioeconomic background of the country of origin.
\end{abstract}

\section{Keywords:}

LIWC; COVID-19; International Leaders; Authenticity; Emotional Tone; Role of Economics; Analysis of Education; Health Behavior

JEL Classification: F29, C55, D63

\section{Authors:}

SANDRA FIGUEIREDO, Psychology Research Centre (CIP), Universidade Autónoma de Lisboa,

Portugal, Email: sfigueiredo@autonoma.pt

MIGUEL DEVEZAS, Universidade Autónoma de Lisboa (UAL), Portugal, Email:

miguel.devezas@gmail.com 
NEUZA VIEIRA, Universidade Autónoma de Lisboa (UAL), Portugal, Email: phe.sun@gmail.com ANDRÉ SOARES, Universidade Autónoma de Lisboa (UAL), Portugal, Email:

andre_acosta90@hotmail.com

\section{Citation:}

SANDRA FIGUEIREDO, MIGUEL DEVEZAS, NEUZA VIEIRA, ANDRÉ SOARES (2020). A psycholinguistic analysis of world leaders' discourses concerning the COVID-19 context: authenticity and emotional tone. International Journal of Social Sciences, Vol. IX(2), pp. 66-81., 10.20472/SS.2020.9.2.004 


\section{INTRODUCTION}

The COVID-19 disease is the current pandemia worldwide causing several disturbances in the countries' policy. That disturbance is affecting different social and economic groups regarding the perspective of comprehension of meaning and action that the discourse of international leaders is moving between January and late April 2020 (Barreneche, 2020). Mixed messaging of leaders and misinformation of social media are simultaneously occurring about SARS-CoV-2 with severe impact in incorrect strategies adopted and associated to the anxiety and incivility behavior of listeners and readers (Bastani and Bahrami, 2020; Cinelli et al., 2020; Kasapoglu and Akbal, 2020; Kim, 2020). The discourses on prevention and information are of upmost importance for social behavior, but moderated by individual and cultural factors (Alafnan, 2020; Bastani and Bahrami, 2020).

Regarding the culture factor, the confinement is not well understood in linguistic and in practice by all socioeconomic groups as well as the confinement measures are changing among countries. Cases such Indonesia and Turkey were not so affected compared to the scenarios of mortality in China, Italy and Spain (Sirkeci and Yucesahin, 2020). The infection spreading of each country determined the public health policy and the discourses on the COVID-19, despite of the general guidelines provided by the World Health Organization. Mitigation methods vary according to each culture and mainly if we examine multicultural countries such as USA and United Kingdom (UK) (Khunti et al., 2020). On the other hand, the COVID-19 psycholinguistic frame enhanced mostly by western leaders empowered great racial and ethnic discrimination attending to the source of the Corona Virus (Zhao et al., 2020): the 'spreading' countries, the contexts perceived as appropriate for vaccine experience lab, and other countries with low literacy levels (Abuelgasim et al., 2020; Gonçalves, 2020).

The communication strategy and the narrative work are also mandatory measures of prevention for the virus spreading and also for cross-cultural concern and ethnic discrimination (Chan Sun and Wah, 2020; Hu et al., 2020). However, the ethnicity, in the perspective of genetics and pathophysiology, is associated to the variance of SARS and specifically concerning the COVID-19 manifestations (Abuelgasim et al., 2020; Martineau et al., 2017). Additionally, countries with high rate of BCG vaccination accomplishment reinforce the low spreading of COVID-19 and similar virus, even considering their immigrants (Miller et al., 2020). Authors such as Abuelgasim et al. (2020) studied past pandemics with the correlation country/ethnicity x diseases spreading (Braun et al., 2013; Chiu et al., 2004; Li et al., 2007), reporting to previous virus and also pre-existent comorbidities. Specific countries and populations developed over time pathologies that emphasize virus spreading like COVID-19 (Wu et al., 2008, 2020). Socioeconomic studies report disavantage for the multi-generational communities (Quinn et al., 2011). 
Attending to this gap related to socioeconomic and genetic traits of populations, the literacy is another problem among minorities and countries (Hutchins et al., 2009). Due to this evidence, the discourses concerning politics and health public measures (and even in the clinical practice, in the hospitals outfront) should have previous alignment to ensure the population' understanding about health outbreaks (Blendon et al., 2008). To help speakers and listeners during the outbreaks, there are available instruments such as Linguistic Inquiry Word Count (LIWC, 2015) to conduct an accurate psycholinguistic coding for discourses with meaning for action (Chung and Pennebaker, 2012; dos Santos et al., 2019; Tausczik and Pennebaker, 2009; Tobin, 2005). The discourse analysis is assisted by a computer-based technique with an algorithm that detects psychological correlation in sentences and words, as well as identifies social grooming (Kim, 2020). Linguistic choices could be restrained and oriented in discourse of international leaders in order to attain an empathic level and easy understanding of measures by people, leading to prevention success and populations' optimism and confidence.

Psycholinguistics (and not only Linguistics) is important to identify discrimination and negative emotions that are spreading in the actual discourses and messaging of countries' leaders on the pandemic COVID-19. Negative emotional tone or lack of autenthicity will lead to negative perceptions regarding mostly the negative other representation (van Dijk, 2005). Also, emotional responses are differently activated by gender during these discourses worldwide and attending to the stressor of the pandemic crisis (van der Vegt and Kleinberg, 2020). Women are producing and responding in a different manner from men toward texts about family and economy safety (men are more focused in economy; women focused in family concerns, van der Vegt and Kleinberg, 2020).

Topic modelling studies within the last four months increased in order to understand the disparities and ascertainity level of discourses in two major settings: social media and leaders' public discourses. Dataset of those studies prove a shift in emotional tone as well as in themes such as health crisis and economy focus (Parvin et al., 2020). According to each leader personality (Tausczik and Pennebaker, 2009) we can find different results in the correlation linguistic dimensions $x$ psychology traits, for each leader and in different periods of the COVID19. In this line of evidence, data will suggest personalities with less/more authentic and positive/negative emotional tone (Pennebaker et al., 2003) by comparison with others. On the other hand, to note that grammar is used with different linguistic markers considering the verbal behavior of individuals and their intention concerning the linguistic community (Skinner, 1957; Rose, 1994; Hirsh and Peterson, 2009).

Respecting the psychological processes displayed by the linguistic features that individuals introduce in their discourses, affective, cognitive and social characteristics are distinguished with computation tools such as LIWC as previously referred (Chung and Pennebaker, 2012; Tausczik and Pennebaker, 2009; Tobin, 2005). Notorious to understand that 
the English is the dominant language in the public health (and political) discourses, considering the translation access to the majority of listeners worldwide. This language dominance implies another concern: perception developed by overall communities and the discrimination by using references and words toward the pandemic situation in China and Japan (Parvin et al., 2020).

The linguistic shape of messages informing over 200 countries influenced indeed the crisis management. The linguistic 'shapes' the interests here considering different psychological meanings. Focusing on psychology and linguistics, several dimensions could be explored for the discourse analysis. We selected emotional tone and authenticity functions during specific verbal repertoires and occurring in separated but close periods. In the same periods several speakers, with high leadership positions across the world, perform their discourses in the same themes. These discourses should be explored as corpora for the information monitoring concerning its impact in the populations' real-life usage. Real life refers to the new daily routines that individuals are obligated to implement for their own safety. Authenticity observed in leaders' discourses reinforce those practices to be implemented in large scale by populations.

However, authenticity is a concept that does not correspond to the truth in politics and other similar fields (Montgomery, 2017). Authentic speeches could be more attractive and well accepted by the listener/reader than the true texts that requires a reality that does not support an appeal style which is constrained by the context (van Dijk, 2005). Considering the word count in political speeches, several times the pronoum "we" is used in authentic way but not corresponding to a true scenario (Petersoo, 2007). Deictic segments are selected by the speaker (normally a top leader) to refer nations in empowered relationship or, on the contrary, to address the lobbies or specific groups which results in discrimination. Valid arguments could be underestimated comparing to other properties such as rethorics and augmented prosody. Time orientation (focus on past, present or future), context (a parliamentary setting, for example) and affect are important to detect authenticity in discourses (Chen and $\mathrm{Hu}, 2019$ ). The main question remains in the affect identification. Computational tools were developed and validated to answer to affect analysis in linguistic segments.

Despite of this review of literature mostly based in investigation published in 2020, attending to the COVID-19 disease and psychosocial implications, data mining and quantitative discourse analysis have been carried out earlier to explore the authenticity dimensions and the related-specific emotional tone. These specific dimensions were studied in the language of politics context and also in the forensic or institutionalised populations (focus: psychotic speech, Caplan et al., 1990; Caplan et al., 2006). Here we focus on politics facing the corona virus crisis. Earlier studies (Cowie et al., 1999; Strauss, 2005) already explored, in real-time, the emotional tone changing between periods but correlating with prosody. Other studies were interested in psychometric scales to evaluate the emotional tone and the person-centered communication in health care settings. Interesting to refer that past studies observed that the high prevention 
behavior, associated to motivation avoidance and major anxiety, were associated to low emotional mood (Baas et al., 2008). This may explain when high levels of emotional tone observed in discourses will contrast to rational competence for decision making (Kuznar and Aviles, 2018; Kwon et al., 2009).

Evidence of earlier scholars focused the importance, for perceptual skills, of emotional characteristics interpreted after a segmentation conducted only with phonemes. Specific phonemes have propensity to appear most in positive mood texts than other (Whissell, 1999). Recently, semantic orientation was crucially understood, in clinical practice, in the relationship between the emotional tone and the existence of cognitive disturbances (Arias et al., 2016). Besides the fact that emotional tone could present semantics desajustment in oral and in textual productions. In the present study we will determine how emotional tone and authenticity properties are present and differentiated along several discourses of eight country leaders focusing the COVID-19 reality. We used a computational based method in order to segment and codify all texts and provide a valid psycholinguistic analysis. All the texts were used in English and as according to their authentic origin (even taking into account the translation official source, see table 1).

\section{METHOD}

\section{Sample}

Two discourses of eight $(\mathrm{N}=16)$ country' leaders were collected to examine emotional tone characteristics and authenticity properties. The discourses occurred between February and April of 2020 and according to the updated pandemic numbers of each country. Countries and their leaders were selected based on the West and East representation of the North Hemisphere and with no ethnicity concepts attached: Germany (Merkel - discourse 1: March $19^{\text {th }} 2020$; discourse 2: April 15 ${ }^{\text {th }}$ 2020), China (JinPing - discourse 1: February 3rd 2020; discourse 2: March $26^{\text {th }} 2020$ ); Spain (Sanchez - discourse 1: March 10 $0^{\text {th }} 2020$; discourse 2: April $18^{\text {th }} 2020$ ); France (Macron - discourse 1: March 16 $6^{\text {th }}$ 2020; discourse 2: April 14 ${ }^{\text {th }} 2020$ ); Italy (Conte -

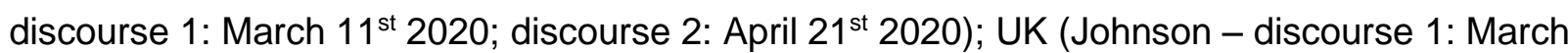
$16^{\text {th }}$ 2020; discourse 2: April 12 ${ }^{\text {nd }} 2020$ ); Russia (Putin - discourse 1: March 25 $5^{\text {th }} 2020$; discourse 2: April 20 $0^{\text {th }} 2020$ ); USA (Trump - discourse 1: March 13 ${ }^{\text {rd }} 2020$; discourse 2: April $19^{\text {th }} 2020$ ). In Figure 1, cases of infected and deceased are presented for each country considering the impact for psycholinguistic data obtained in the next section. 
Figure 1. Number of cases infected by COVID-19 and number of deceased by country considering the period between February and April 2020.

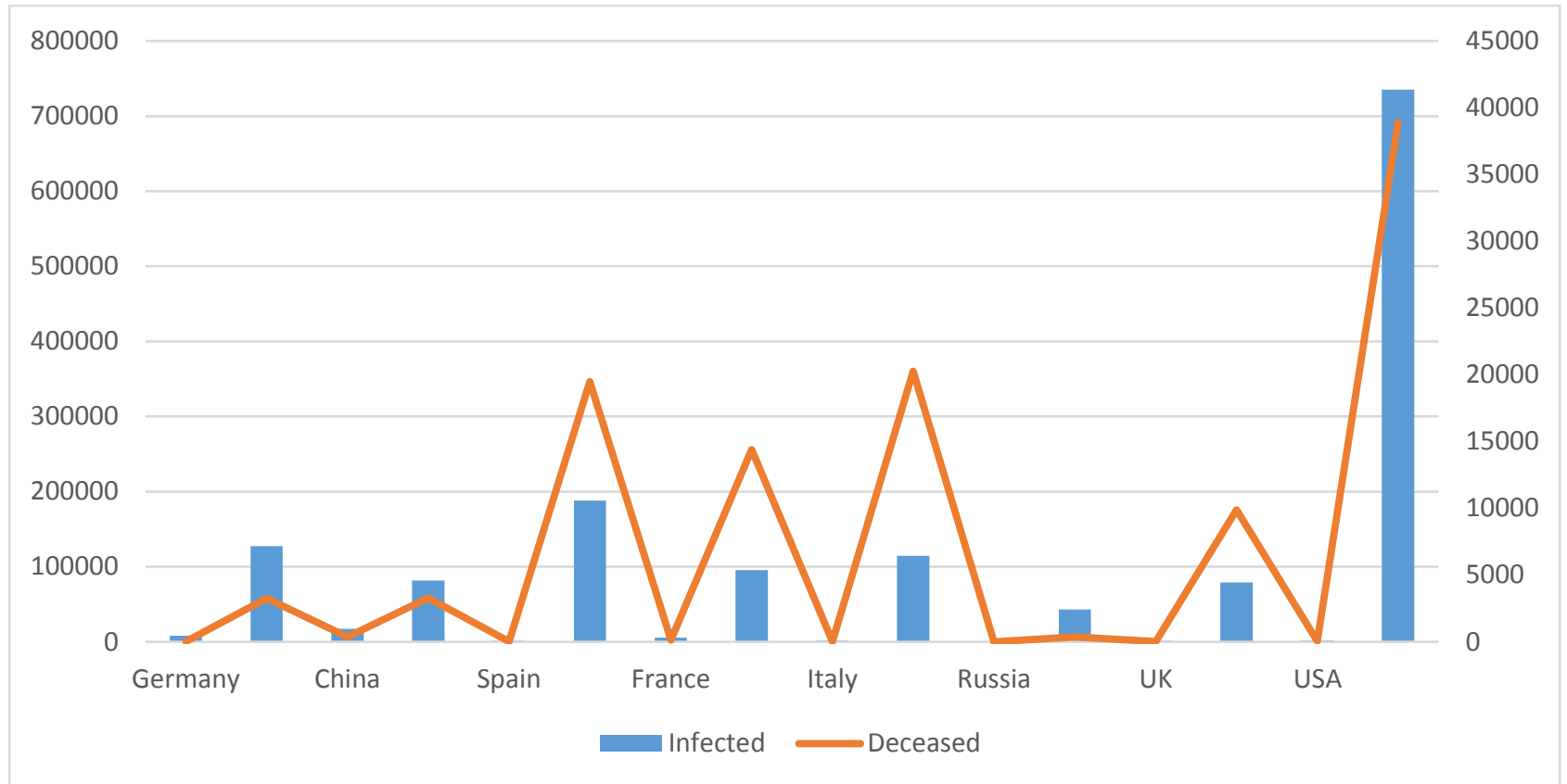

\section{Instruments and procedures}

The Linguistic Inquiry and Word Count (LIWC 2015, v. 1.6.0. 2019) was the basis of the instrument developed originally for this study computation. It was developed a specific dictionary for this psycholinguistic context, based in the LIWC, and this original version created for the trial study was administered to establish the segmentation and codification of 16 international discourses, focusing leadership and COVID-19. The LIWC was developed and validated (and adapted for a specific number of languages and population) to compute whole or parts of texts, to categorize in segments and then to attribute language dimensions. When the data is displayed, codes, languages dimensions and scores are given. LIWC is a computation tool as an advanced dictionary and rapid word counting system with no statistical complexity and with feasible processing. However, attending to the COVID-19 and current political worldwide context, we had computed an original dictionary to ensure that segments correspond to complete text analysis. These characteristics enable linguistic classification and personality analysis of subjects based on their texts (verbal behavior as evidence).

The texts were coded considering the linguistic dimensions and psychological categories (examples of each subset in Table 1). After the dataset of 39073 words concluded, a correlation was computed to link linguistic samples with low/high emotional properties (and taking into account the linguistic style of the country' leaders) and authenticity properties (honesty and vulnerability, observed across lexicon used). To noticed that the word count will not be addressed attending to the lexicon frequency, the grammar organization and syntax properties 
of the eight languages because all the discourses are presented in English and not in the languages of origin. Also this version of LIWC considered the English idiom.

Concerning the procedure and content analysis, the algorithm of LIWC displayed a categorization that established the scoring for emotional tone for each text and period, as well as segmentation associated to each category (codification). For emotional tone the cut-off point is < .50. For authenticity, the word analysis was interpreted according to the researchers' perspective who conducted the texts selection and their distribution in the LIWC.

Table 1. Discourses (extracts) of eight leaders presented, in public settings, in two periods COVID-19 theme.

\begin{tabular}{|c|c|c|}
\hline Country & Discourse 1 & Discourse 2 \\
\hline Germany & $\begin{array}{l}\text { "Fellow citizens,Coronavirus is } \\
\text { changing daily life our country } \\
\text { dramatically at the present. Our idea } \\
\text { of normality of public life, social } \\
\text { togetherness - all this is being put to } \\
\text { the test as never before. Millions of } \\
\text { you cannot go to work, your children } \\
\text { cannot go to school kindergarten } \\
\text {,theatres and cinemas and shops are } \\
\text { closed ,and,perhaps what is most } \\
\text { difficult, we all miss social encounters } \\
\text { that we otherwise take for granted. } \\
\text {,each of us has many questions and } \\
\text { concerns in a situation like this ,about } \\
\text { days ahead. I'm addressing you this } \\
\text { unconventional way today because I } \\
\text { want tell you what guides me as } \\
\text { Federal Chancellor all my colleagues } \\
\text { in the Federal Government this } \\
\text { situation. This is part of what open } \\
\text { democracy is about: that we make } \\
\text { political decisions transparent and } \\
\text { explain them. That we justify and } \\
\text { communicate our (...)" } \\
\text { Merkel } 19 / 03\end{array}$ & $\begin{array}{l}\text { "Ladies and gentlemen ,in last few } \\
\text { days we have been working very } \\
\text { intensively on our meeting today and } \\
\text { today we discussed with each other } \\
\text { via video conference where our } \\
\text { country stands concerning } \\
\text { coronavirus epidemic. l'd like to thank } \\
\text { the federal states that we have all } \\
\text { followed through with the common } \\
\text { policy we decided on. And that we } \\
\text { have also met today to jointly design } \\
\text { next phase. What has led us today? } \\
\text { First of all ,l'd like to once again very } \\
\text { warmly thank all the people in } \\
\text { Germany ,the citizens who have } \\
\text { changed their lives ,who have } \\
\text { reduced contacts ,who accept the } \\
\text { restrictions, not because they want to } \\
\text { please the government ,but because } \\
\text { they want to help their fellows. This is } \\
\text { something very strong and important } \\
\text { that our country is experiencing at the } \\
\text { moment,even with all the restrictions } \\
\text {,and it shows that if something really } \\
\text { good is to arise our country (...)" } \\
\text { Merkel } 15 / 04\end{array}$ \\
\hline China & $\begin{array}{l}\text { "After the outbreak of the new } \\
\text { coronavirus pneumonia in Wuha ,on } \\
\text { January } 7 \text {,when I chaired the } \\
\text { meeting of the Standing Committee } \\
\text { of the Political Bureau of the Central } \\
\text { Committee ,I put forward } \\
\text { requirements for the prevention and } \\
\text { control of the new coronavirus } \\
\text { pneumonia. On January } 20 \text {, } \\
\text { specifically issued instructions on the } \\
\text { prevention and control epidemic } \\
\text {,pointing out that epidemic must be } \\
\text { highly valued,and the prevention and } \\
\text { control work should be done with all } \\
\text { our strength. It requires party } \\
\text { committees and governments all } \\
\text { levels and relevant departments to } \\
\text { put the safety health people first. } \\
\text { Take effective measures to resolutely } \\
\text { curb spread epidemic. On January } 22 \\
\text {,in view of the rapid spread epidemic } \\
\text { and the serious challenges (...)" } \\
\text { Xi Jinping } 15 / 02\end{array}$ & $\begin{array}{l}\text { "Dear Colleagues, } \\
\text { It is good to join you. Let me begin by } \\
\text { expressing my sincere appreciation } \\
\text { to His Majesty King Salman and } \\
\text { Saudi Arabia for having done } \\
\text { tremendous work of communication } \\
\text { and coordination to make this summit } \\
\text { possible. Facing the COVID-19 } \\
\text { outbreak that caught us all by } \\
\text { surprise, the Chinese government } \\
\text { and Chinese people have been } \\
\text { undaunted we took this formidable } \\
\text { task. From day one our fight against } \\
\text { the outbreak, we have put people's } \\
\text { life health first. We have acted } \\
\text { according to the overall principle of } \\
\text { shoring up confidence, strengthening } \\
\text { unity,ensuring science-based control } \\
\text {, treatment and imposing targeted } \\
\text { measures. We have mobilized the } \\
\text { whole nation, set up collective control } \\
\text { (...)" } \\
\text { Xi Jinping } 26 / 03\end{array}$ \\
\hline
\end{tabular}




\begin{tabular}{|c|c|c|}
\hline Spain & $\begin{array}{l}\text { "Good evening and my thanks to the } \\
\text { media for coming this press } \\
\text { conference. As you all know,I have } \\
\text { just taken part in an extraordinary } \\
\text { meeting of the European Council that } \\
\text { has been held by video-conference. } \\
\text { We have addressed coronavirus } \\
\text { crisis and I can announce you that in } \\
\text { the coming days the European } \\
\text { Commission and also the Eurogroup } \\
\text { will announce different packages of } \\
\text { joint economic financial measures. } \\
\text { But, if you agree, I am willing to speak } \\
\text { about Europe a bit later. } \\
\text { As you now, we are facing a global } \\
\text { health emergency that already } \\
\text { affects more than } 100 \text { countries and } \\
\text { which thus requires a coordinated } \\
\text { and multilateral response (...)" }\end{array}$ & $\begin{array}{l}\text { "Good afternoon. } \\
\text { It has been more than a month since } \\
\text { day I appeared ,for first time, to } \\
\text { announce state of Alarm and to } \\
\text { approve very severe measures of } \\
\text { social isolation. In these few weeks } \\
\text {,although they have seemed eternal } \\
\text {,the virus has left a trace of pain in } \\
20.000 \text { families who have lost a loved } \\
\text { one, often without consolation, we } \\
\text { have said other appearances, of a } \\
\text { last hug ,of a last goodbye. To them } \\
\text {,I convey a message of deep regret } \\
\text { on behalf of the whole of Spanish } \\
\text { society and the Government of } \\
\text { Spain. And to all those people we } \\
\text { have lost ,as soon as possible, we } \\
\text { will pay the tribute (...) }\end{array}$ \\
\hline & Sanchez 10/03 & Sanchez 18/04 \\
\hline France & $\begin{array}{l}\text { "Women and men of France, } \\
\text { On Thursday night I spoke you about } \\
\text { health crisis that our country is } \\
\text { confronting. Up until that point ,some } \\
\text { of you epidemic was maybe a distant } \\
\text { notion; it has become an immediate } \\
\text { and pressing reality. As I announced } \\
\text {,the Government has taken strong } \\
\text { measures slow spread virus. } \\
\text { Nurseries ,primary and secondary } \\
\text { schools and universities are closed } \\
\text { as from today. On Saturday evening } \\
\text {,restaurants all shops not considered } \\
\text { be essential for the life of the Nation } \\
\text { also closed their doors. Gatherings of } \\
\text { over } 100 \text { people were also prohibited. } \\
\text { France has never had to make such } \\
\text { decisions - which are,.. ,exceptional } \\
\text { and temporary - in peacetime. They } \\
\text { were taken in an orderly, ,prepared } \\
\text { way ,based on scientific } \\
\text { recommendations and with one sole } \\
\text { objective: to protect us from spread } \\
\text { virus. (...)" } \\
\text { Macron 16/03 }\end{array}$ & $\begin{array}{l}\text { "Frenchwomen,Frenchmen, } \\
\text { My dear compatriots, We are living } \\
\text { through difficult times. We are all } \\
\text { feeling fear distress right now, our } \\
\text { parents, and ourselves ,we face this } \\
\text { dreadful, invisible and unpredictable } \\
\text { virus. Tiredness Weariness some } \\
\text {,mourning sorrow for others. This } \\
\text { period is even more difficult deal with } \\
\text { when there are several of you living } \\
\text { in a cramped apartment, when you } \\
\text { don't have access to the means of } \\
\text { communication necessary to learn ,to } \\
\text { have fun ,to communicate. It's even } \\
\text { harder when there is tension, when } \\
\text { there is violence in a family's daily life } \\
\text { We are all aware of ,this period,the } \\
\text { loneliness and sadness our senior } \\
\text { community. And yet, thanks to our } \\
\text { efforts ,we have improved every day. } \\
\text { (...)" }\end{array}$ \\
\hline Italy & $\begin{array}{l}\text { "I'd like to begin by thanking first of all } \\
\text { once again ,the doctors, health } \\
\text { workers ,the researchers who as I } \\
\text { speak you are working tirelessly in } \\
\text { hospitals to fight health emergency } \\
\text {,treat our patients. } \\
\text { My thanks also go to all of you, who } \\
\text { are respecting measures that the } \\
\text { government has taken to counter } \\
\text { spread virus. I thank you because i } \\
\text { do know that you are changing your } \\
\text { lifestyle,you are making sacrifices, i } \\
\text { do know it is not easy, but you know } \\
\text { that with this renunciations - small or } \\
\text { large - they are making a great } \\
\text { valuable contribution to country. Italy } \\
\text {,we can say it strong, with pride, is } \\
\text { proving be a great nation ,a great } \\
\text { community, united and responsible. } \\
\text { This moment the whole world is } \\
\text { looking at us: they certainly look at us } \\
\text { for numbers of infection,they see a } \\
\text { country in difficulty. But they also } \\
\text { appreciate us because we are } \\
\text { showing great vigor,great resistance. } \\
\text { (...)" }\end{array}$ & $\begin{array}{l}\text { "Thank you President ,Dear } \\
\text { Members, Dear Members, today's } \\
\text { information allows me to offer } \\
\text { Parliament a complete picture of the } \\
\text { most recent initiatives that the } \\
\text { Government has adopted internally } \\
\text { and an update on the initiatives that } \\
\text {,at European level ,are planned to } \\
\text { face the epidemiological emergency } \\
\text { from COVID-19. This step is carried } \\
\text { out in the clear awareness, of those } \\
\text { who speak you but also of the entire } \\
\text { Government, of the need to fully } \\
\text { involve Parliament in particular in a } \\
\text { phase in which the action of the } \\
\text { Government ,either for the } \\
\text { extraordinary character or for the } \\
\text { pervasive scope of the emergency } \\
\text { we are facing, it directly detects } \\
\text { people's primary assets: health } \\
\text {,freedom,economic initiative ,work. } \\
\text { We come to the initiatives taken } \\
\text { internally. As you know,very complex } \\
\text { debate is taking place on (...)" } \\
\text { Conte } 21 / 04\end{array}$ \\
\hline
\end{tabular}




\begin{tabular}{|c|c|c|}
\hline & Conte 11/03 & \\
\hline Russia & $\begin{array}{l}\text { "Citizens Russia, friends, } \\
\text { I'm reaching out you issue that has } \\
\text { become a, matter of concern for all } \\
\text { of us. We are witnessing an, acute } \\
\text { escalation coronavirus epidemic } \\
\text { on a global scale. Number new cases } \\
\text { continues grow many countries. } \\
\text { Global economy as a whole is at risk } \\
\text {,and is already expected shrink. } \\
\text { Taking precautionary measures,we } \\
\text { have been largely able prevent } \\
\text { infection from rapidly } \\
\text { spreading limit incidence rate. } \\
\text { However,we have understand that } \\
\text { Russia cannot insulate itself from this } \\
\text { threat ,simply considering its } \\
\text { geography. There are countries } \\
\text { along our borders that have already } \\
\text { been seriously affected by epidemic } \\
\text {,which means that all objectivity it is } \\
\text { impossible stop it from spilling over } \\
\text { Russia. That said ,being professional } \\
\text {,well organized proactive is what we } \\
\text { can do (...)" } \\
\text { Putin } 25 / 03\end{array}$ & $\begin{array}{l}\text { "Good afternoon,colleagues. } \\
\text { Taking part our work today are } \\
\text { experts in countering epidemics } \\
\text {,leading virologists, infectious } \\
\text { disease specialists, well heads } \\
\text { research centers. Your professional } \\
\text { assessments and recommendations } \\
\text { are vitally important for us, federal } \\
\text { and regional authorities. This is why } \\
\text { we will constantly be keeping touch } \\
\text { with you. } \\
\text { You are well aware that situation } \\
\text { remains difficult. Regrettably } \\
\text {,epidemic keeps spreading. Number } \\
\text { people infected with coronavirus is } \\
\text { growing,and not only Moscow which } \\
\text { was first encounter threat. However } \\
\text {,we understood ,knew were } \\
\text { preparing this, we knew that } \\
\text { epidemic would begin spill over other } \\
\text { regions. Unfortunately, this has also } \\
\text { happened. However , we } \\
\text { managed somewhat slow down this } \\
\text { (...)" } \\
\text { Putin 20/04 }\end{array}$ \\
\hline UK & $\begin{array}{l}\text { "Good afternoon everybody ,thank } \\
\text { you very much for coming. I wanted } \\
\text { to bring everyone up to date with the } \\
\text { national fight back against the new } \\
\text { coronavirus and the decisions that } \\
\text { we've just taken in COBR for the } \\
\text { whole of the UK. We said last week } \\
\text {,our objective is to delay and flatten } \\
\text { peak epidemic by bringing forward } \\
\text { right measures at right time, so that } \\
\text { we minimise suffering and save lives. } \\
\text { everything we do is based } \\
\text { scrupulously on best scientific } \\
\text { advice. Last week we asked } \\
\text { everyone stay at home if you had one } \\
\text { of two key symptoms: a high } \\
\text { temperature or new and continuous } \\
\text { cough. Today, we need go further } \\
\text {,because according to SAGE [the } \\
\text { Scientific Advisory Group for } \\
\text { Emergencies] it looks as though } \\
\text { we're now approaching the fast } \\
\text { growth part of the upward curve. } \\
\text { Without drastic action, cases could } \\
\text { double every } 5 \text { or } 6 \text { days. (...)" } \\
\text { Jonhson } 16 / 03\end{array}$ & $\begin{array}{l}\text { "Good afternoon. I have today left } \\
\text { hospital after a week in which the } \\
\text { NHS has saved my life. No question. } \\
\text { It's hard to find words express my } \\
\text { debt, but before I come to that, I want } \\
\text { to thank everyone in the entire UK for } \\
\text { the effort and the sacrifice you have } \\
\text { made, are making. When the sun is } \\
\text { out and the kids are at home, when } \\
\text { the whole natural world seems that its } \\
\text { loveliest and the outdoors is so } \\
\text { inviting ,I can only imagine how tough } \\
\text { it has been to follow the rules on } \\
\text { social distancing. I thank you } \\
\text { because so many millions and } \\
\text { millions people across this country } \\
\text { have been doing right thing. Millions } \\
\text { going through the hardship of self } \\
\text { isolation faithfully, patiently, and with } \\
\text { thought and care others well as } \\
\text { themselves. I want you know this } \\
\text { Easter Sunday, I do believe that your } \\
\text { efforts are worth it are daily proving } \\
\text { their worth. Because although we } \\
\text { mourn every day (...)" } \\
\text { Jonhson 12/04 }\end{array}$ \\
\hline USA & $\begin{array}{l}\text { "Thank you very much ,everyone. } \\
\text { Thank you. Thank you. A beautiful } \\
\text { day in the Rose Garden. Appreciate } \\
\text { everybody being here. Today ,l'd like } \\
\text { provide an update to the American } \\
\text { people on several decisive new } \\
\text { actions we're taking our very vigilant } \\
\text { effort to combat and ultimately defeat } \\
\text { coronavirus. We've been working } \\
\text { very hard this. We've made } \\
\text { tremendous progress. When you } \\
\text { compare what we've done other } \\
\text { areas of the world, it's pretty } \\
\text { incredible. A lot of that had do with } \\
\text { the early designation and the closing } \\
\text { of the borders. And, as you know } \\
\text {,Europe was just designated as the } \\
\text { hotspot right now, We closed that } \\
\text { border a while ago. So that was lucky } \\
\text { or through talent or through luck. Call }\end{array}$ & $\begin{array}{l}\text { "Thank you very much. I'd like to } \\
\text { begin by saying that we're continuing } \\
\text { to negotiate with the Democrats get } \\
\text { our great workers and small } \\
\text { businesses all over country taken } \\
\text { care of. I think we -- we're getting } \\
\text { close to a deal. It could happen. It } \\
\text { could happen. A lot of good work has } \\
\text { been going on ,We could have an } \\
\text { answer tomorrow. We're going to see } \\
\text { what exactly does take place. We're } \\
\text { also looking at helping our hospitals } \\
\text { and our rural hospitals, who have } \\
\text { been hurt very badly. The rural } \\
\text { hospitals ,for a long time ,have not } \\
\text { been treated properly. We're looking } \\
\text { to help them, and beyond. So we're } \\
\text { looking hospitals also, as part of the } \\
\text { package. We'll see how comes out. }\end{array}$ \\
\hline
\end{tabular}




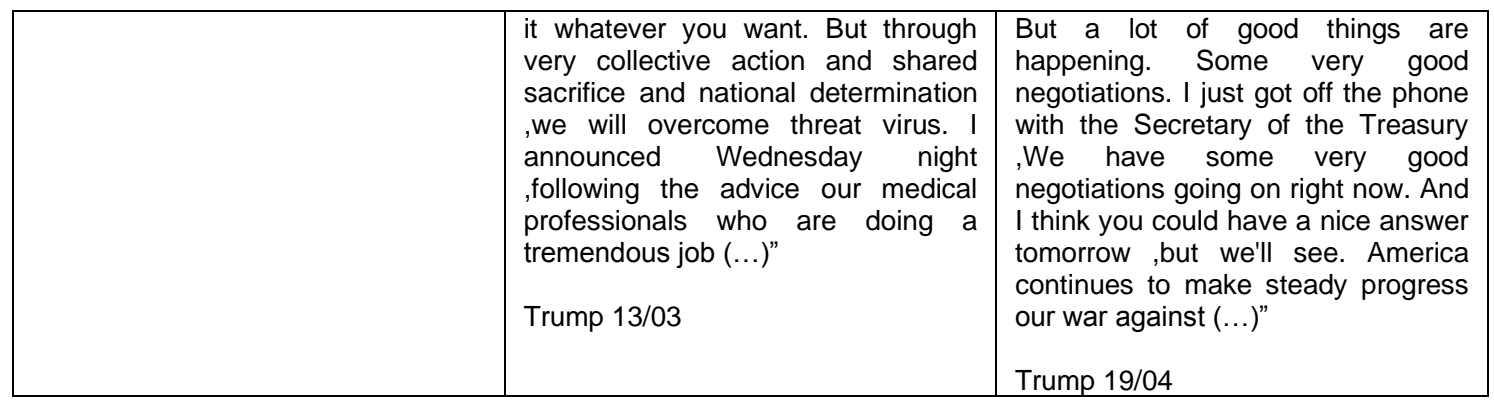

\section{Results and Discussion}

Attending to LIWC analysis method and considering the emotional tone and authenticity of the leaders' discourses, percentages revealed interesting insights about the differences among international leaders in their management of the COVID-19 context. Those insights were directly observed through verbal behavior repertoire. In the German case (A. Merkel) the political discourse changed from the first period to the second one with focus in health and gaining in emotional tone percentage (discourse $1-49.89 \%$; discourse $2-81.14 \%$ ). The authenticity remained the same for the two appearances of the Chanceler (considering only the discourses examined as corpora for this study), ranging between $21 \%$ and $26 \%$. Examining discourses in the East, particularly in China, the results showed a directive speech and the emotional tone was evident in both discourses (> .50), higher in the second discourse. In the second speech the negative traits, specifically for anger, were visible. The emotional tone is grounded by the scenario of increased health crisis that caused disturbance in the community daily habits of chinese population. The chinese leader revealed consciousness and analytical thinking about the corona virus, but with negative words mostly used.

Considering authenticity, the chinese leader presented a very low score (9.91) compared to other leaders in the first discourse. Slightly increased the authentic discourse in the phase 2 (12.42). Only China can be compared in low authenticity speech with the Russian case that presented even lower emotional tone. In Russia, the COVID-19 appeared in the President discourses as a 'non-political' matter but causing disturbance for economy and demography. The main focus was economy and death avoidance which justifies the emotional tone as well as low levels of authenticity (proximity and humble, for example, were not evident). Very differently for UK scenario, where Johnson developed interventions with two distinct emotional profiles: first discourse almost absent of emotional tone (35.76); second discourse was very emotional (80.01). However, the US President also showed in LIWC higher scores (73.33 - first discourse) for emotional tone, as well as positive values for authenticity. But his discourse is marked by negativity words and a misperception about the COVID-19 pandemic consequences. In the discourse 1 the health situation is slightly mentioned contrary to the period 2 with more consciousness about the situation and the emotional tone diminished (65.29). See Figure 2. 
Figure 2. Scores (in \%) for emotional tone (1) and authenticity (2) in the discourses of 8 country leaders: two periods of speech intervention in analysis.

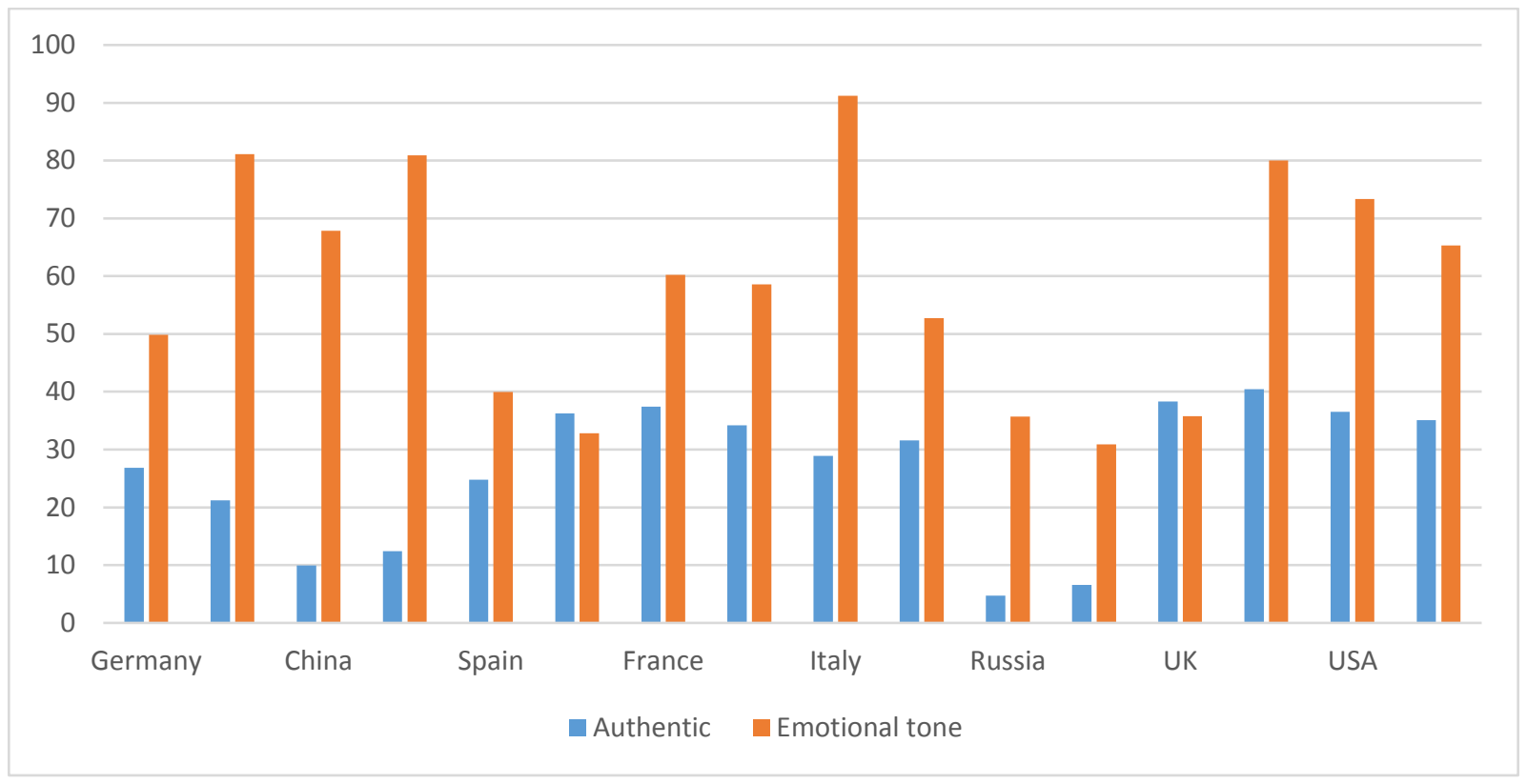

Still considering the Chinese and Russian cases, however in emotional tone they diverge with prejudice for the Russian President (percentages above < .36). In Spain, the President was characterized, through LIWC, as very analytic in the first discourse contrary to the second intervention with negative emotions well pronounced such as anxiety and anger. The levels of emotional tone for Spain are significantly low in the two moments $(<.40)$ but decreasing in the second discourse. The scenario of higher rates of death grounded this change in his discourse. However, the Spain Leader presented high scores for authenticity (between 24.8 and 36.25), contrary to China and Russia as we mentioned previously. The analytic reasoning of Spain explains also the authentic speech. Focusing on France, the emotional tone is higher (> .59) and very similar to the emotions identified in North America President discourse.

Optimism and reinforced leadership were the themes most used during the discourses of Macron (France). Similarly, higher levels of authenticity (> .34). In sum, the discourse with the highest emotional tone was verified in Italy first discourse. These results can be explained considering the death rate that Italy experienced during the last months caused only by COVID19. But the second discourse of the Italian President was very different with words pointing out the distrust felt $(<.53)$, even maintaining the prominent emotional tone considering the cut-off as established by LIWC. The discourses with lowest emotional tone were detected in Russia. Attending to authentic traits of speeches, the most authentic were identified in UK, France and US. Contrary to Russia and China. See Figure 2. 
Considering the literature that verified the authenticity function in textual evidence, the authentic speeches are more attractive and simbolic to move the population' behavior (Montgomery, 2017; Petersoo, 2007; van Dijk, 2005). The real information is not fully presented to avoid mixed messaging and to control public opinion divergence. It should be noticed that the leaders of countries such as US and France used more deitic segments considering their own perception of empowerment nation. This linguistic pattern was observed in previous studies on authenticity (Petersoo, 2007). On the other hand, all subjects presented time-oriented speeches (Chen and $\mathrm{Hu}, 2019$ ) despite of their negativity and anxiety in high representative samples (Baas, 2008). The case of China is very particular considering that the virus origin was in Wuhan and the leader' discourses presented higher emotional tone but lack of authenticity (unrevealed information that is currently causing feeling of disruption about transparency) (Zhao et al., 2020).

Regarding emotional tone examined in this specific trial study, several cases presented negative emotions caused by COVID-19. These results are supported by past studies of van Dijk (2005) that concluded the correlation of negative emotional tone in political speeches with the negative perception of other countries causing group instability. Changes between discourses, considering one month gap for each leader, were expected and were confirmed. The emotional tone, compared to authenticity function, revealed more changes in discourses from period 1 to period 2 and in different ways: from low to high tone and vice-versa. UK and Germany cases presented the most significant scenarios of changes from low tone $(<.50)$ to the highest percentages in all samples. This evidence is maintained by past studies (Cowie et al., 1999; Parvin et al., 2020). Further psycholinguistics analysis is ongoing in this study to determine the personality and action, in COVID-19 world context, through leaders' verbal behavior. The pandemic situation demands replicated studies by using artificial intelligence methods (Nail et al., 2020; Zhao et al., 2020).

This work was funded by national funds through FCT - Fundação para a Ciência e a Tecnologia - as part the project CIP/UAL - Refa Ref $^{a}$ UIDB/04345/2020

\section{References}

Abuelgasim, E., Saw, L. J., Shirke, M., Zeinah, M., Harky, A. 2020. 'COVID-19: Unique public health issues facing Black, Asian and minority ethnic communities', Current Problems in Cardiology, 100621. https://doi.org/10.1016/j.cpcardiol.2020.100621

AlAfnan, M. A. 2020. 'COVID 19-The Foreign Virus: Media Bias, Ideology and Dominance in Chinese and American Newspaper Articles', International Journal of Applied Linguistics and English Literature, vol. 9, no. 1, pp. 56-60. https://doi.org/10.7575/aiac.ijalel.v.9n.1p.56

Arias Tapia, S. A., Martínez-Tomás, R., Gómez, H. F., Hernández del Salto, V., Sánchez Guerrero, J., Mocha-Bonilla, J. A., ... Chicaiza Redin, V. 2016. 'The dissociation between polarity, 
semantic orientation, and emotional tone as an early indicator of cognitive impairment', Frontiers in computational neuroscience, vol. 10, no. 95, pp. 1-9. https://doi.org/10.3389/fncom.2016.00095

Baas, M., De Dreu, C. K., Nijstad, B. A. 2008. A meta-analysis of 25 years of mood-creativity research: Hedonic tone, activation, or regulatory focus?.Psychological bulletin, vol. 134, no. 6, pp. 779. https://doi.org/10.1037/a0012815

Barreneche, S. M. 2020. 'Somebody to blame: on the construction of the other in the contexto of the COVID-19 outbreak'. Society Register, vol. 4, no. 2, pp. 19-32.

https://doi.org/10.14746/sr.2020.4.2.02

Bastani, P. \& Bahrami, M. A. 2020. 'COVID-19 Related Misinformation on Social Media: A Qualitative Study from Iran', Journal of medical Internet research. https//doi.org/10.2196/18932

Blendon, R. J., Koonin, L. M., Benson, J. M., Cetron, M. S., Pollard, W. E., Mitchell, E. W., ... Herrmann, M. J. 2008. 'Public response to community mitigation measures for pandemic influenza', Emerging infectious diseases, vol. 14, no. 5, pp. 778. https://doi.org/10.3201/eid1405.071437

Braun, L., Wolfgang, M., Dickersin, K. 2013. 'Defining race/ethnicity and explaining difference in research studies on lung function', Eur Respir J, vol. 41, no. 6, pp. 1362-1370. https://doi.org/10.1183/09031936.00091612

Caplan, R., Perdue, S., Tanguay, P. E., Fish, B. 1990. 'Formal thought disorder in childhood onset schizophrenia and schizotypal personality disorder', Journal of Child Psychology and Psychiatry, vol. 31, no. 7, pp. 1103-1114. https://doi.org/10.1111/j.1469-7610.1990.tb00849.x

Caplan, R., Siddarth, P., Bailey, C. E., Lanphier, E. K., Gurbani, S., Shields, W. D., Sankar, R. 2006). 'Thought disorder: a developmental disability in pediatric epilepsy', Epilepsy \& Behavior, vol. 8, no. 4, pp. 726-735. https://doi.org/10.1016/j.yebeh.2006.03.009

Chan Sun, M. \& Lan Cheong Wah, C. B. 2020. 'COVID-19 in Mauritius: Discourse Analysis of the Public Health Response Against the Pandemic', Claude Bernard, COVID-19 in Mauritius: Discourse Analysis of the Public Health Response Against the Pandemic.

http://dx.doi.org/10.2139/ssrn.3593537

Chen, X. \& Hu, J. 2019. 'Evolution of US presidential discourse over 230 years: A psycholinguistic perspective', International Journal of English Linguistics, vol. 9, no. 4, pp. 28-41. https://doi.org/10.5539/ijel.v9n4p28

Chiu, R.W.K., Tang, N.L.S., Hui, D.S.C., Chung, G.T.Y., Chim, S.S.C., Chan, K.C.A., Y. Sung, L.Y.S. Chan, Y. Tong, W. Lee, P.K.S. Chan, Y.M.D. Lo. 2004. ACE2 gene polymorphisms do not affect outcome of severe acute respiratory syndrome, Clin Chem, 50, vol. 9, pp. 1683-1686. https://doi.org/10.1373/clinchem.2004.035436

Chung, C. K. \& Pennebaker, J. W. 2012. 'Linguistic inquiry and word count (LIWC)', Applied Natural Language Processing, pp. 206-229. https://doi.org/10.4018/978-1-60960-741-8.ch012

Cinelli, M., Quattrociocchi, W., Galeazzi, A., Valensise, C. M., Brugnoli, E., Schmidt, A. L., ... Scala, A. 2020. 'The covid-19 social media infodemic', arXiv preprint arXiv:2003.05004.

Cowie, R., Douglas-Cowie, E., Romano, A. 1999. Changing emotional tone in dialogue and its prosodic correlates. In ESCA Tutorial and Research Workshop (ETRW) on Dialogue and Prosody, pp. 41-46. 
Dos Santos, W. R., Ramos, R. M., Paraboni, I. 2019. 'Computational personality recognition from Facebook text: Psycholinguistic features, words and facets', New Review of Hypermedia and Multimedia, vol. 25, no. 4, pp. 268-287. https://doi.org/10.1080/13614568.2020.1722761

Hirsh, J. B. \& Peterson, J. B. 2009. 'Personality and language use in self-narratives', Journal of Research in Personality, vol. 43, no.3, pp. 524-527. https://doi.org/10.1016/j.jrp.2009.01.006

Hutchins, S. S., Fiscella, K., Levine, R. S., Ompad, D. C., McDonald, M. 2009. 'Protection of racial/ethnic minority populations during an influenza pandemic', American journal of public health, vol. 99, S2, pp. 261-270. https://doi.org/10.2105/AJPH.2009.161505

Kasapoglu, A. \& Akbal, A. 2020. 'Relational Sociological Analysis of Uncertainties: The case of COVID-19 In Turkey', Advances in Social Sciences Research Journal, vol. 7, no. 4, pp. 197-228. https://doi.org/10.14738/assri.74.8116

Khunti, K., Singh, A. K., Pareek, M., Hanif, W. 2020. Is ethnicity linked to incidence or outcomes of covid-19? https://doi.org/10.1136/bmj.m1548

Kim, B. 2020. 'Effects of social grooming on incivility in COVID-19', Cyberpsychology, Behavior, and Social Networking. https://doi.org/10.1089/cyber.2020.0201

Kuznar, L. A. \& Aviles, W. 2018. Comparative Analysis of Kim Family Political Discourse. NSI, Inc Boston United States.

Kwon, W., Clarke, I., Wodak, R. 2009. 'Organizational decision-making, discourse, and power: integrating across contexts and scales', Discourse \& Communication, vol. 3, no. 3, pp. 273-302. https://doi.org/10.1177/1750481309337208

Li, W., Sui, J., Huang, I. C., Kuhn, J. H., Radoshitzky, S. R., Marasco, W. A., ... Farzan, M. 2007. 'The S proteins of human coronavirus NL63 and severe acute respiratory syndrome coronavirus bind overlapping regions of ACE2', Virology, 367, vol. 2, pp. 367-374.

https://doi.org/10.1016/j.virol.2007.04.035

Martineau, A. R., Jolliffe, D. A., Hooper, R. L., Greenberg, L., Aloia, J. F., Bergman, P., ... Goodall, E. C. 2017. 'Vitamin D supplementation to prevent acute respiratory tract infections: systematic review and meta-analysis of individual participant data', bmj, 356, i6583.

https://doi.org/10.1136/bmj.i6583

Miller, A., Reandelar, M. J., Fasciglione, K., Roumenova, V., Li, Y., Otazu, G. H. 2020. 'Correlation between universal BCG vaccination policy and reduced morbidity and mortality for COVID19: an epidemiological study', MedRxiv. https://doi.org/10.1101/2020.03.24.20042937

Nail, B., Rabehi, A., Bekhiti, B., Arbaoui, T. 2020. A new design of an adaptive model of infectious diseases based on artificial intelligence approach: Monitoring and forecasting of COVID-19 epidemic cases, https://doi.org/10.1101/2020.04.23.20077677

Parvin, M. 2020. 'Dynamic Learning Platform for Dynamic EFL Learners: A New Journey to Navigate Effective E-Learning Program for English Education at the University Level', International Journal of English Linguistics, vol. 10, no. 2, pp. 170-183. https://doi.org/10.5539/ijel.v10n2p170

Pennebaker, J. W., Mehl, M. R., Niederhoffer, K. G. 2003. 'Psychological aspects of natural language use: Our words, our selves', Annual Review of Psychology, vol. 54, no. 1, pp. 547-577. https://doi.org/10.1146/annurev.psych.54.101601.145041 
Quinn, S. C., Kumar, S., Freimuth, V. S., Musa, D., Casteneda-Angarita, N. Kidwell, K. 2011. 'Racial disparities in exposure, susceptibility, and access to health care in the US H1N1 influenza pandemic', American journal of public health, vol. 101, no. 2, pp. 285-293.

https://doi.org/10.2105/AJPH.2009.188029

Rose, J. C. D. 1994. 'O livro Verbal Behavior de Skinner e a pesquisa empírica sobre o comportamento verbal', Psicol. teor. pesqui, vol. 10, no. 3, pp. 495-510.

Sirkeci, I. \& Yucesahin, M. 2020. 'Coronavirus and Migration: Analysis of Human Mobility and the Spread of Covid-19', Migration Letters, vol.17, no.2, pp. 379-398.

https://doi.org/10.33182/ml.v17i2.935

Skinner, B.F.1957. Verbal Behavior. Acton, Massachusetts: Copley.

https://doi.org/10.1037/11256-000

Strauss, C. 2005. Analyzing discourse for cultural complexity. In Finding culture in talk (pp. 203242). Palgrave Macmillan, New York. https://doi.org/10.1007/978-1-137-05871-3_6

Tausczik, Y. R. \& Pennebaker, J. W. 2009. 'The psychological meaning of words: LIWC and computerized text analysis method', Journal of Language and Social Psychology, vol. 29, no. 1, pp. 2454. https://doi.org/10.1177/0261927x09351676

Tobin, R. M. 2005. Measuring emotions with the linguistic inquiry and word count (LIWC), PsycEXTRA Dataset. https://doi.org/10.1037/e525752006-001

van der Vegt, I. \& Kleinberg, B. 2020. 'Women worry about family, men about the economy: Gender differences in emotional responses to COVID-19', arXiv preprint arXiv:2004.08202.

Van Dijk, T. A. 2006. 'Discourse and manipulation', Discourse \& society, vol. 17, no. 3, pp. 359383. https://doi.org/10.1177/0957926506060250

Whissell, C. 1999. 'Phonosymbolism and the emotional nature of sounds: evidence of the preferential use of particular phonemes in texts of differing emotional tone', Perceptual and Motor Skills, vol. 89, no. 1, pp. 19-48. https://doi.org/10.2466/pms.1999.89.1.19

Wu, Y., Tseng, C., Cheng, M., Ho, H., Shih, S., Chiu. D. 2008. 'Glucose-6-phosphate dehydrogenase deficiency enhances human coronavirus 229E infection', J Infect Dis, vol. 197, no. 6, pp. 812-816. https://doi.org/10.1086/528377

Wu, C., Chen, X., Cai, Y., Zhou, X., Xu, S., Huang, H., ... Song, J. 2020. 'Risk factors associated with acute respiratory distress syndrome and death in patients with coronavirus disease pneumonia in Wuhan, China', JAMA internal medicine.

https://doi.org/10.1001/jamainternmed.2020.0994

Zhao, S., Musa, S. S., Lin, Q., Ran, J., Yang, G., Wang, W., Lou, Y., Yang, L., Gao, D., He, D., Wang, M. H. 2020. 'Estimating the unreported number of novel coronavirus (2019-nCoV) cases in China in the first half of January 2020: A data-driven modelling analysis of the early outbreak', Journal of Clinical Medicine, vol. 9, no. 2, p. 388. https://doi.org/10.3390/jcm9020388 